\title{
Identifikasi Gen Sub1A Pada Varietas Tebu Tahan Genangan
}

\author{
Identification of Sub1A Gene in Flooding Tolerant Commercially Superior \\ of Sugar Cane Varieties
}

\author{
Author(s): Ayu Puspita Arum ${ }^{(1) *}$; Sholeh Avivi (1) \\ (1) Universitas Jember \\ * Corresponding author: ayu.puspita@unej.ac.id
}

$$
\text { Submitted: } 28 \text { Jul } 2020 \text { Accepted: } 25 \text { Aug } 2020 \quad \text { Published: } 30 \text { Sep } 2020
$$

\begin{abstract}
ABSTRAK
Tebu dapat tumbuh pada berbagai kondisi lingkungan yang cukup beragam termasuk pada lahan marginal seperti lahan yang sering tergenang. Lahan tergenang dapat menurunkan produksi tebu cukup signifikan. Tujuan penelitian ini adalah menemukan gen toleran kebasahan yang terdapat pada 8 varietas unggul komersial tebu yang tahan genangan yaitu PS 881, PS 862, PS 882, Kentung, PSJT 941, Bulu Lawang, PS 865 dan Kidang Kencana serta mengidentifikasi kemiripannya dengan gen Sub1A. Dengan diperolehnya gen toleran kebasahan pada varietas tebu tahan genangan di harapkan varietas tebu tersebut dapat ditanam di lahan yang sering tergenang dan dapat memberikan tambahan sumbangan produksi gula secara Nasional. Sehingga pada akhirnya dapat mengurangi impor yang secara kontinu dilakukan pemerintah setiap tahun dan sebagai solusi peningkatan produksi pangan berbasis lahan daratan dalam menghadapi perubahan iklim. Tahapan untuk memperoleh dan mengidentifikasi gen toleran kebasahan atau tahan genangan adalah pengkondisian lahan tanaman tebu tergenang, isolasi DNA dari tanaman tebu yang tergenang, penentuan konsentrasi dan kemurnian DNA yang diperoleh, konfirmasi DNA yang diisolasi dengan elektroforesis dan identifikasi gen Sub 1 A pada DNA sampel metode PCR dengan primer Sub 1 A 203 R/F dan kontrol Positif DNA tanaman padi transgenik yang mengandung gen Sub 1 A. Hasil kegiatan penelitian dapat disimpukan bahwa 8 varietas unggul komersial tebu yaitu PS 881, PS 862, PS 882, Kentung, PSJT 941, Bulu Lawang, PS 865 dan Kidang Kencana semuanya mempunyai gen yang mirip dengan gen Sub 1 A. Dengan varietas PS 881 dan Kentung menghasilkan band sekuens DNA target gen Sub 1 A paling tebal.
\end{abstract}

\section{Kata Kunci:}

Genangan;

Gen Sub1A;

Identifikasi gen

Sub1A;

\section{Keywords:}

Flooding;

Subla gene;

SublA gene identification;

\section{ABSTRACT}

Sugar cane can grow in a variety of environmental conditions that are including on marginal land such as flooded land. Flooded land can significantly reduce sugar cane production. This study aimed to find a flooding tolerant gene in 8 floodings tolerant of sugarcane commercially superior varieties such as PS 881, PS 862, PS 882, Kentung, PSJT 941, Bulu Lawang, PS 865, and Kidang Kencana and identify their similarities with the SublA gene. Finding of flooding tolerant gene in commercially superior varieties of sugar cane. It was expected that the commercially superior varieties of sugar cane could be planted in flooding land and could provide additional contributions to national sugar production. Finally, it could reduce sugar import continuously by the government every year and as the solution to increasing food production based land area in the face of climate change. The steps were setting flooding conditions inland. Then, sugar cane was conducted DNA isolation, determination of concentration and purity, DNA confirmation through electrophoresis, and identification of Sub 1 A gene on DNA sample through PCR method with Sub 1 A $203 R$ / F primers and positive control of GMO rice plants containing Sub 1 A gene. The results were concluded that 8 commercially superior varieties of sugarcane such as PS 881, PS 862, PS 882, Kentung, PSJT 941, Bulu Lawang, PS 865, and Kidang Kencana, all of it have gene similar to the Sub 1 A gene. PS 881 and Kentung produced the thickest DNA sequence or gene was similar to the Sub 1 A gene. 


\section{PENDAHULUAN}

Tebu (Saccharum officinarum L.) merupakan salah satu tanaman industri yang cukup penting di Indonesia. Indonesia memiliki luasan pertanaman tebu pada tahun 2010 sebesar 429,4 ribu ha dan produksi sebesar 2,2 juta ton serta produktivitas tebu sebesar 5,1 ton per ha (Statistik \& 2015, n.d.). Dengan produksi sebesar itu Indonesia masih harus secara terus menerus mengimpor sebanyak 2 juta ton gula per tahun selama 5 tahun terakhir ini.

Kekurangan produksi tersebut dapat dipecahkan dengan memperluas lahan pertanaman tebu. Lahan pertanaman yang punya potensi cukup baik untuk perluasan tanaman tebu adalah lahan yang kadangkadang tergenang seperti lahan pasang surut, lahan rawa, dan lahan yang sering terpapar banjir. Luas lahan rawa di Indonesia diperkirakan mencapai 33.393.570 hektar. Lahan tebu tergenang yang sudah memanfaatkan tanaman tebu toleran genangan di dapati di Australia. Genangan air merupakan salah satu cekaman abiotik yang dapat menghambat proses fotosintesis dan respirasi terhadap tanaman tebu sehingga produktivitas tebu menjadi rendah. (Armstrong, 2002). Varietas tebu toleran genangan mampu bertahan hingga beberapa bulan dalam kondisi tercekam genangan dan mampu membentuk aerenchyme pada batangnya, sedangkan tebu yang peka hanya mampu bertahan tumbuh dalam beberapa hari saja serta tidak mampu membentuk aerenchyme (Glaz et al., 2004).

Beberapa karakter fisiologis yang berubah pada saat tebu tercekam genangan adalah: (1) menurunnya tingkat transpirasi, (2) menurunnya tingkat fotosintetis tetapi konduktansi stomata meningkat, (3) menurunnya tingkat pertumbuhan, (4) respirasi menjadi lebih tinggi. Pengaruh cekaman genangan terhadap respirasi tergantung pada varietas dan fase fisiologi, (5) terjadi perubahan proses metabolisme dari aerobik menjadi anaerobik, (6) serapan nutrisi oleh akar menurun dan jumlah daun menguning meningkat (Tetsushi, Studies, \& 2007, n.d.). Juga di laporkan selama cekaman genangan terjadi tanaman melakukan perubahan morfologi, anatomi, fisiologi, dan biokimia untuk beradaptasi dengan lingkungan tercekam. Besarnya kerusakan akibat cekaman genangan dipengaruhi oleh beberapa faktor diantaranya adalah tinggi genangan, durasi atau lama waktu genang, dan kecepatan aliran air (Tetsushi et al., n.d.). Karakter yang berkaitan dengan ketahanan terhadap genangan akan di gunakan untuk menyeleksi tebu tahan genangan yang akan diidentifikasi gen toleran kebasahan yang identik dengan gen Sub1A. Gen Sub1 yang merupakan gen toleran genangan air yang selama ini sering diinsersikan pada DNA tanaman transgenik untuk menghasilkan tanaman yang toleran genangan . Berdasarkan penelitian (Xu \& Mackill, n.d.), Lokus Sub-1 terpetakan pada kromosom 9 berukuran $200 \mathrm{~kb}$ dan berperan dalam variasi toleransi genangan kultivar padi (Santos et al., 2013);(Schreinert et al., 2017).

Data-data fisiologi ini mendukung teori bahwa strategi ketahanan terhadap genangan berlangsung melalui konservasi karbohidrat, represi elongasi sel, dan peningkatan kapasitas fermentasi (Perata \& Voesenek, 2007). Genangan mengakibatkan akumulasi etilen yang kemudian menginduksi transkripsi gen Sub1 A sehingga terjadi akumulasi protein Sub1A. Selanjutnya Sub1A menghambat ekspansi A (ExpA) dan sukrosa sintase (Sus 3) sehingga menghambat pertumbuhan. Sub1A meningkatkan transkripsi gen yang berkaitan dengan fermentasi sehingga terjadi akumulasi mRNA dan peningkatan aktivitas Pyruvate decarboxylase (Pdc) dan Alcohol dehydrogenase (Adh). Kondisi Fermentasi akan membuat glikolisis dapat berlanjut sehingga menghasilkan ATP untuk 
survival. Namun, laju produksi etanol tidak jauh berbeda dengan genotip yang tidak mengandung gen Sub1 A, mengindikasikan bahwa induksi Pyruvate decarboxylase (Pdc) dan Alcohol dehydrogenase (Adh) tidak terlalu krusial. Sub1A menghambat gen yang berkaitan dengan elongasi sel dan katabolisme karbohidrat. Degradasi pati menghasilkan sumber glukosa untuk glikolisis dan pertumbuhan. Padi yang mengekspresi Sub1A, laju elongasi rendah, pati dan karbohidrat yang terkumpul dapat digunakan untuk mempertahankan perlambatan sintesis ATP melalui fermentasi. Sub1C yang mengontrol gen $\alpha$ amilase (Ramy3D) dihambat oleh Sub1A. Gibberellins (GA) terlibat dalam regulasi ekspresi Sub1C. Namun, efek tersebut terhadap ekspresi Ramy3D bersifat tidak langsung, mengingat promotor gen ini yang tidak mengandung elemen GARE diperlukan untuk regulasi GA. Peningkatan regulasi GA. Peningkatan regulasi Ramy3D oleh kandungan gula didapatkan pada Sub1A defisien. Sub1A juga bertanggung jawab pada restriksi feedback produksi etanol. Gen Sub1 ini di harapkan ada pada tanaman tebu yang toleran genangan (Gusmiatun et al., 2015); (Hoque \& Ability, 2017); (Tiwari, 2018); (Banayo, Mabesa-Telosa, Singh, \& Kato, 2019) \& (D. J. Mackill et al., 2012). Keterkaitan Sub-1 dalam ketahanan tanaman terhadap genangan seperti disajikan pada Gambar 1 berikut (Fukao \& Bailey-Serres, 2008).

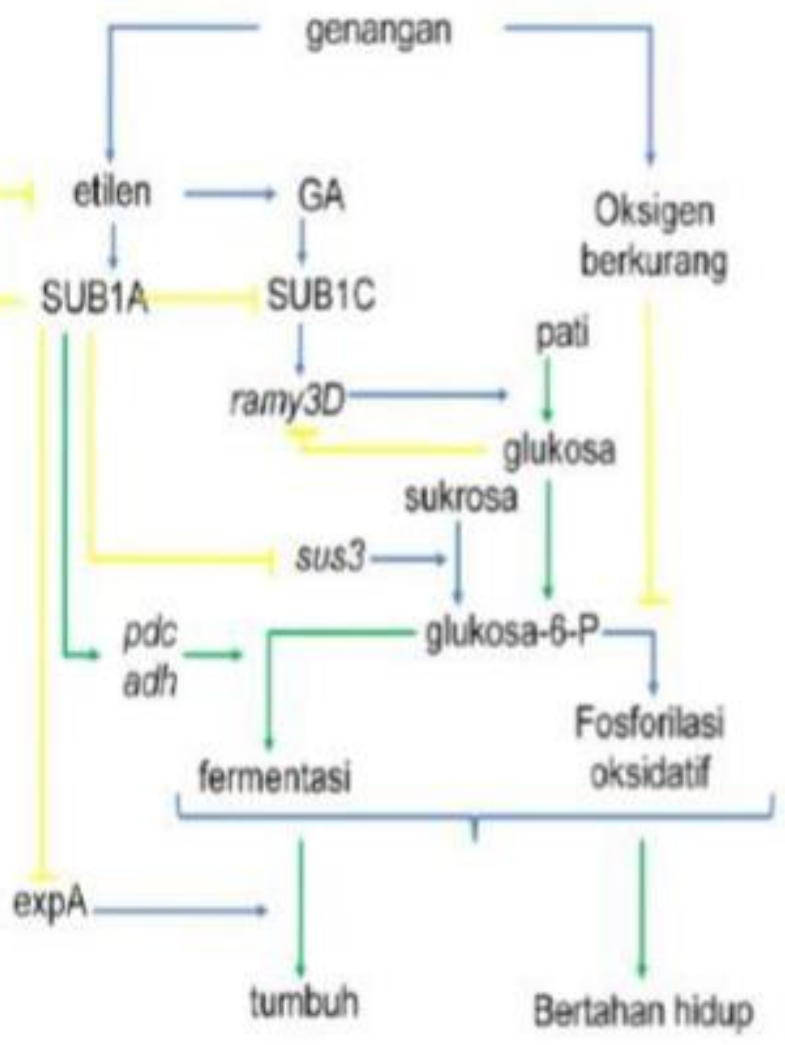

Gambar 1. Keterkaitan Gen Sub-1 dalam Ketahanan Tanaman terhadap Genangan (Fukao \& Bailey-Serres, 2008)

Figure 1. Biosynthesis of Sub-1 Gene in the Regulation of Flooding tolerant

Berdasarkan penelitian Ramadhan (2015) bahwa 8 varietas tebu (PS 881, PS 862, PS 882, Kentung, PSJT 941, Bulu Lawang, PS 865 dan Kidang Kencana) telah terkonfirmasi tahan genangan berdasarkan karakter fisiologisnya. Oleh karena itu, penelitian ini bertujuan untuk mengkonfirmasi keberadaan gen tahan 
genangan pada 8 varietas tebu tersebut yang mirip dengan gen Sub 1 A yang merupakan gen tahan genangan yang ditemukan pada tanaman-tanaman lain yang tahan terhadap cekaman abiotik berupa genangan.

\section{METODOLOGI}

Penelitian dilaksanakan di UPT Agrotechnopark, Fakultas Pertanian, Universitas Jember, Desa Jubung Kecamatan Sukorambi dan Laboratorium C-DAST Universitas Jember. Waktu penelitian dimulai pada bulan Oktober 2017 sampai Desember 2017. Penelitian ini dilakukan dalam beberapa tahap yaitu

1. Pengkondisian tanaman tebu yang tahan genangan menurut (Begum, 2003) dengan modifikasi yaitu Pengeprasan tanaman tebu varietas (PS 881, PS 862, PS 882, Kentung, PSJT 941, BL, PS 865 dan KK) yang berumur 10 bulan. Lalu, Anakan tanaman tebu dibiarkan tumbuh. Lahan tanaman tebu yang sudah di kepras dibersihkan dari sisa batang dan daun tebu serta pembersihan saluran air dari gulma. Anakan yang berumur 14 hari diberi pupuk Urea dan pupuk organik sambil tanah-tanah disekitar tanaman tebu dibumbun agar pupuk tidak mudah hilang terbawa air saat hujan. Setelah 1 minggu, tanaman tebu diberikan perlakuan genangan dengan ketinggian $30 \mathrm{~cm}$ (air menutupi akar tanaman tebu hingga mencapai batang paling bawah dari tanaman tebu) selama 7 hari.

2. Isolasi DNA dari tanaman tebu yang digenangani dengan jumlah 3 sampel pada setiap varietasnya. Pada tahapan ini bertujuan untuk memisahkan DNA dari senyawa-senyawa pengotor lainnya dalam sel tumbuhan yaitu polisakarida, polifenol dan protein. Pada tahapan ini membandingkan 2 metode isolasi DNA yaitu isolasi DNA metode SDS (Cheng, Guo, Yi, Pang, \& Deng, 2003) dan metode CTAB (Chalmers, 1994);(Syahfitri, Staf, Program, \& Agroekoteknologi, 2017)untuk mendapatkan metode isolasi DNA yang terbaik dengan tingkat kemurnian DNA yang didapat sangat tinggi.

3. Pengukuran konsentrasi dan kemurnian DNA dengan spektrofotometer dengan panjang gelombang 260-280 nm (Murtiyaningsih, Pertanian, \& Jember, n.d.).

$$
\text { Rumus konsentrasi DNA } \mu \mathrm{g} / \mu \mathrm{l}=\frac{\text { (absorbansi sampel } \lambda 260-\text { absorbansi blanko)X } 40 \mu \mathrm{g} / \mu \mathrm{l}}{5}
$$

Rumus kemurnian DNA $=\frac{\text { (absorbansi } \lambda 260-\text { absorbansi blanko) }}{(\text { Absorbansi } \lambda 280-\text { Absorbansi blanko) }}$

4. Konfirmasi keberadaaan DNA tebu yang sudah diisolasi secara visual dengan elektroforesis DNA. Prosedur Elektroforesis yaitu membuat $1 \%$ gel Agarosa ( 1 gram bubuk Agarosa dilarutkan dalam $100 \mathrm{ml}$ buffer TAE). Penambahan larutan Ethidium Bomida $3 \mu l$ pada larutan gel Agarosa \& dikocok sampai tercampur. Penuangan gel Agarosa pada cetakan dan pasang sisir sumur sampel dan dibiarkan hingga mengeras. Penambahan larutan Loading dye $3 \mu 1$ pada sampel $1 \mu 1$ dan dicampur. Pemasukan sampel dengan konsentrasi $(0,3 \mu \mathrm{g} / \mu \mathrm{l})$ yang sudah bercampur dengan loading dye ke sumur sampel elektroforesis. Proses elektroforesis tegangan listrik 100 volt selama 25 menit. Pemasukan gel hasil elekroforesis ke gel doc untuk disinari sinar UV sehingga band-band DNA muncul dan terlihat (Murtiyaningsih et al., n.d.). 
5. Identifikasi gen Sub 1 A pada DNA tebu dengan metode PCR dengan primer Sub 1A 203 R/F dan kontrol Positif DNA tanaman padi transgenik yang mengandung gen Sub 1 A. Prosedur PCR DNA yaitu membuat formulasi bahan PCR DNA dalam 1 reaksi PCR DNA per sampel volumenya $25 \mu 1$ (DNA $1 \mu 1$, PCR DNA mix KIT merek "Bioline" 12,5 $\mu$ 1, Primer Sub 1 A R $0,5 \mu 1$, Primer Sub 1 A F $0,5 \mu 1$ dan Nuclease free water $10,5 \mu 1$ ). menghidupkan mesin PCR dan memasang suhu serta waktu predenaturasi $95^{\circ} \mathrm{C}, 1$ menit, denaturasi $95^{\circ} \mathrm{C}, 15$ detik, annealing $50^{\circ} \mathrm{C}, 15$ detik, extention $72^{\circ} \mathrm{C}, 10$ detik dan pendinginan $4^{\circ} \mathrm{C}, 16$ menit. Lalu, mematikan mesin PCR. DNA hasil PCR dielektroforesis dengan marker DNA ladder $1 \mathrm{~Kb}$ atau 100 bp "Nexmark" untuk memastikan DNA yang terbentuk berukuran sama sesuai dengan ukuran DNA gen Sub 1 A (Murtiyaningsih et al., n.d.).

\section{HASIL DAN PEMBAHASAN \\ Isolasi DNA dengan Metode SDS dan CTAB}

Pada tahap ini bertujuan untuk memilih metode isolasi DNA yang paling tepat untuk mendapatkan konsentrasi dan kemurnian yang tinggi dari DNA tanaman tebu yang diisolasi.

Tabel 1. Perbandingan Konsentrasi dan Kemurnian DNA dengan Metode SDS dan Metode CTAB

Table 1. Comparison of Concentration and Purity of DNA with SDS Method and CTAB Method

\begin{tabular}{lccc}
\hline $\begin{array}{l}\text { Sampel DNA } \\
(8 \text { Varietas Tebu })\end{array}$ & Metode Isolasi DNA & $\begin{array}{l}\text { Konsentrasi DNA } \\
(\mu \mathrm{g} / \mu \mathrm{l})\end{array}$ & Kemurnian DNA \\
\hline PS 881 & CTAB & 0,584 & 1,97 \\
PS 862 & CTAB & 0,624 & 1,90 \\
PS 882 & CTAB & 0,104 & 1,91 \\
Kentung & CTAB & 0,040 & 1,93 \\
PSJT 941 & SDS & 0,360 & 1,67 \\
Bulu Lawang & SDS & 0,312 & 1,69 \\
PS 865 & SDS & 0,392 & 1,75 \\
Kidang Kencana & SDS & 0,304 & 1,73 \\
\hline
\end{tabular}

Tabel 1 menunjukkan bahwa konsentrasi $(\mu \mathrm{g} / \mu \mathrm{l})$ dan kemurnian dari DNA yang sudah diisolasi dari 8 varietas tanaman tebu diperoleh bahwa metode isolasi DNA dengan CTAB menghasilkan tingkat kemurnian yang lebih tinggi dibandingkan dengan metode isolasi DNA dengan SDS. Semakin murni DNA yang diperoleh maka semakin baik digunakan untuk menjadi bahan identifikasi gen target yang diinginkan, karena jika DNA yang diperoleh memiliki tingkat kemurnian yang rendah maka senyawa pengotor (polisakarida, protein dan polifenol) yang terkandung masih banyak (Cheng et al., 2003). Senyawa pengotor tersebut dapat mendegradasi DNA. Oleh karena itu, metode isolasi DNA yang tepat untuk mengisolasi DNA dari 8 varietas tanaman tebu berdasarkan Tabel 1 adalah isolasi DNA metode CTAB.

\section{Hasil Elektroforesis dari 8 Varietas Tebu \\ Setelah didapatkan metode isolasi DNA tanaman tebu yang tepat pada tahapan sebelumnya maka pada tahapan ini bertujuan untuk mengkonfirmasi DNA}


tebu dari 8 varietas yang sudah diisolasi dengan metode CTAB secara visual dengan elektroforesis. Hasil elektroforesis pada DNA dari 8 varietas tebu dapat dilihat pada Gambar 2 berikut.

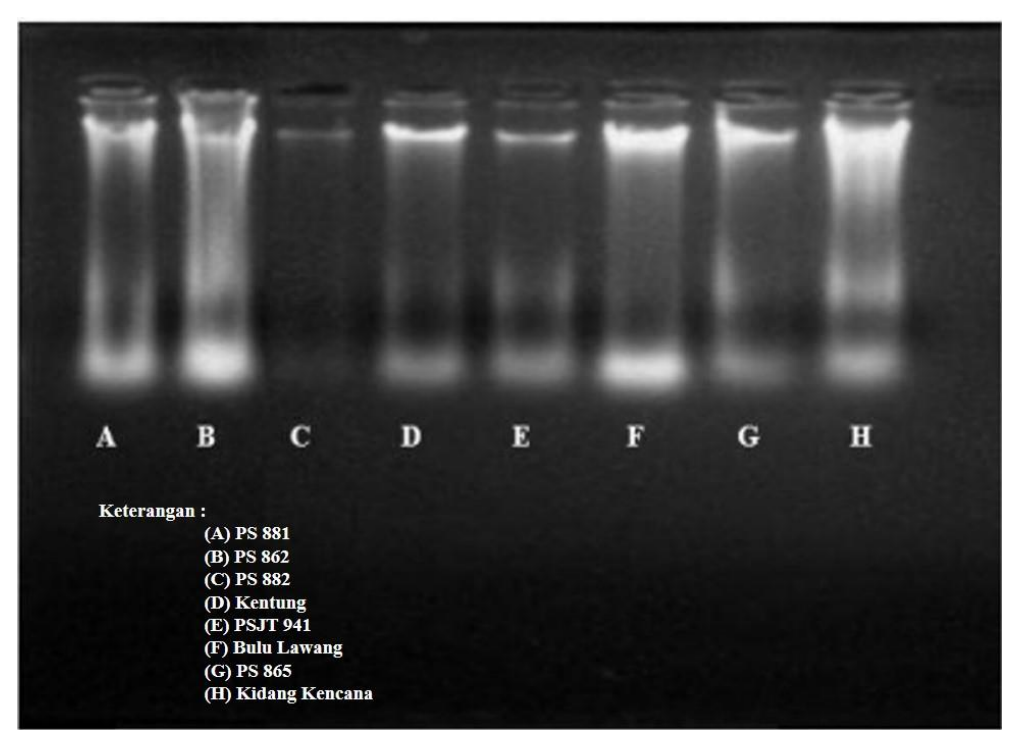

Gambar 2. Hasil Elektroforesis dari Isolasi DNA 8 Varietas Tebu dengan Metode CTAB

Figure 2. Electrophoresis Results from DNA Isolation of 8 Sugarcane Varieties using the CTAB Method

Tabel 2. Konsentrasi DNA dari 8 Varietas Tebu

Table 2. Concentration of DNA from 8 Sugarcane Varieties

\begin{tabular}{cc}
\hline Sampel DNA & Konsentrasi DNA $(\boldsymbol{\mu g} / \boldsymbol{\mu l})$ \\
\hline PS 881 & 0,936 \\
PS 862 & 0,384 \\
PS 882 & 0,040 \\
Kentung & 1,168 \\
PSJT 941 & 0,376 \\
Bulu Lawang & 1,384 \\
PS 865 & 1,816 \\
Kidang Kencana & 0,640 \\
\hline
\end{tabular}

Gambar 2 dan Tabel 2 menunjukkan hasil isolasi DNA dan konsentrasi hasil isolasi DNA dengan menggunakan metode CTAB pada 8 varietas tanaman tebu.

\section{Hasil PCR Gen Target (Gen Sub 1 A) dari 8 Varietas Tebu Tahan Genangan}

Pada tahap ini bertujuan untuk mengidentifikasi gen tahan genangan pada tanaman tebu yang mirip dengan gen tahan genangan gen Sub 1 A dari tanaman padi transgenik.
Gambar 4 menunjukkan bahwa dari 8 varietas tebu (B,C,D,E,F, G,H,I) yang digenangi diperkirakan memiliki gen Sub 1 A yang ditunjukkan dengan terbentuknya deretan band DNA pada baris ke 2 dari bawah yang berukuran 200 bp. Menurut (Septiningsih et al., 2009), bahwa sekuens DNA yang merupakan gen Sub 1 A memiliki ukuran band sekitar 203 bp. Selain itu, Jika dibandingkan dengan kontrol positif yaitu padi transgenik (A) yang memang mengandung gen Sub 1 A menunjukkan band DNA target gen Sub 1 
A paling tebal ada di band DNA baris ke 2 dari bawah. Oleh karena itu, Berdasarkan gambar 4 dapat disimpulkan pada 8 varietas tanaman tebu yang digenangi yang diuji, semuanya mengandung gen Sub 1 A. Dengan band DNA target Gen Sub 1 A yang paling tebal varietas tebu PS 881 dan Kentung. Semakin tebal band DNA yang terbentuk menunjukkan semakin banyak sekuens DNA target gen Sub 1 A yang terbentuk. Hasil tersebut sesuai dengan hasil penelitian dari (Avivi et al., 2018); (Permana et al., 2018) dan (RAMADHAN, n.d.) yang menunjukkan bahwa berdasarkan karakter morfologi dan anatomi 8 varietas tebu tersebut toleran terhadap genangan.
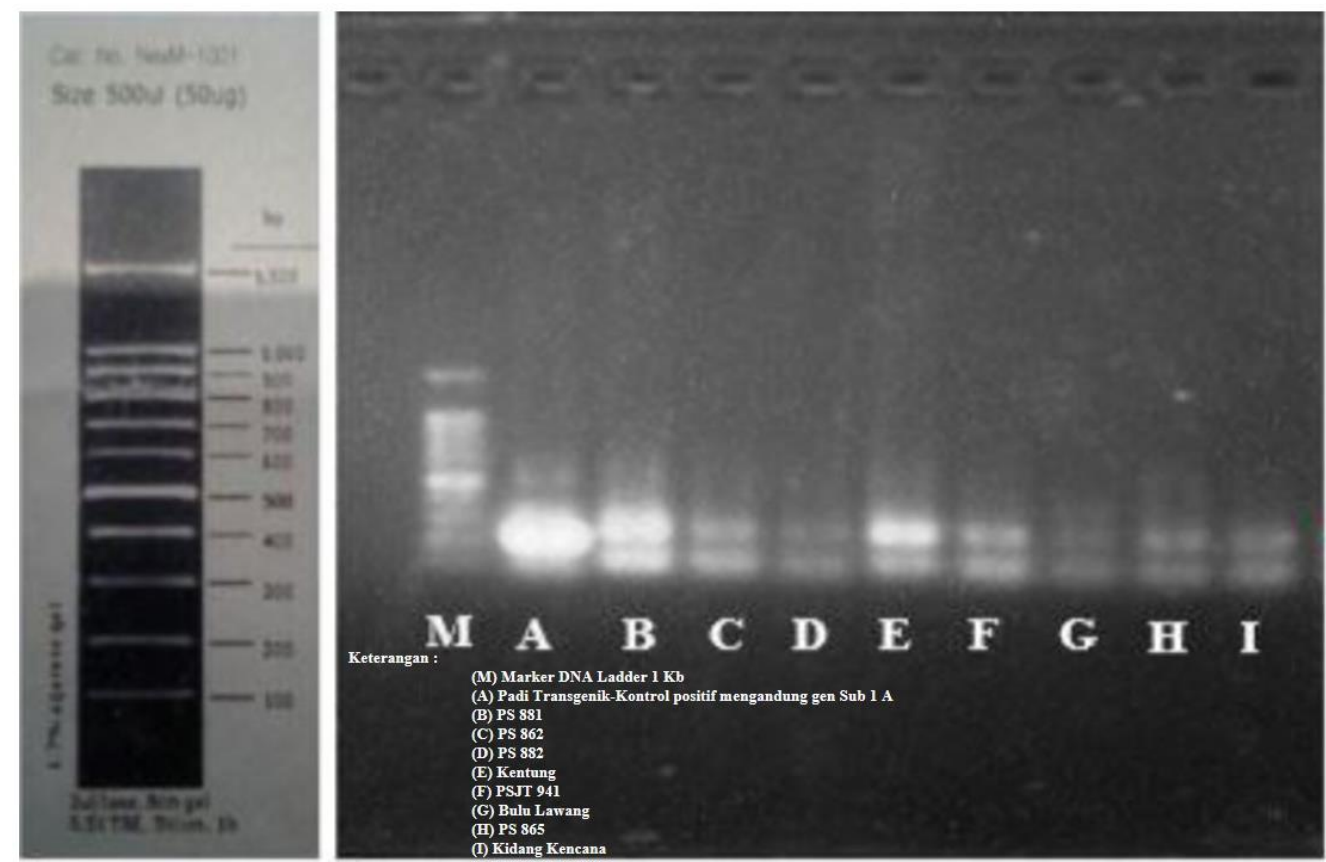

Gambar 3. Hasil PCR DNA Target Gen Sub 1 A dari 8 Varietas Tebu Tahan Genangan dengan Primer Sub 1 A 203 R/F serta Marker DNA Ladder 100 bp

Figure 3. PCR Results of DNA Targets for Sub 1 A Genes of 8 Flooding Tolerant Sugarcane Varieties with Primer Sub 1 A 203 R / F and 100 bp DNA Ladder Marker

\section{KESIMPULAN}

Berdasarkan hasil penelitian kami dapat disimpukan bahwa 8 varietas unggul komersial tebu yaitu PS 881, PS 862, PS 882, Kentung, PSJT 941, Bulu Lawang, PS 865 dan Kidang Kencana semuanya mempunyai gen tahan genangan yang mirip dengan gen Sub 1 A. Dengan varietas PS 881 dan Kentung menghasilkan band sekues DNA target gen Sub 1 A paling tebal. Saran dari kegiatan penelitian ini perlu dilakukan analisa sequensing pada hasil PCR 8 varietas unggul komersial tebu tersebut untuk mengetahui urutan sekuens basa nukleotida dari DNA sampel hasil PCR yang mirip dengan urutan sekuens basa nukleotida dari gen Sub 1 A.

\section{DAFTAR PUSTAKA}

Armstrong, W. (2002). Root growth and EQ metabolism under oxygen deficiency. Plant Roots: The Hidden Half, 729761.

Avivi, S., Syamsunihar, A., Soeparjono, S., Q \& Chozin, M. (2018). Toleransi Berbagai Varietas Tebu terhadap Penggenangan pada Fase Bibit Berdasarkan Karakter Morfologi dan Anatomi Tolerance of Sugarcane 
Varieties toward Waterlogging at Seedling Stage based on Morphological Characteristics and Anatomy. 46(April), 103-110.

Banayo, N. P. M., Mabesa-Telosa, R. C., EQ Singh, S., \& Kato, Y. (2019). Improved early season management of sub1 rice varieties enhances postsubmergence recovery and yield. Experimental Agriculture, 55(1), 105.

Begum, M. K. (2003). Effects of WaterLogging on Juice Quality and Yield of Sugarcane. Stress physiology View project. Article in Pakistan Journal of Biological Sciences, 6(13), 11511155.

Chalmers, K. J. (1994). Detection of genetic diversity and selective gene introgression in coffee using RAPD markers The effect of Zebularine on Recombination in Barley View project Barley View project. Springer, 87(8), 934-940.

Cheng, Y.-J., Guo, W.-W., Yi, H.-L., Pang, X.-M., \& Deng, X. (2003). An efficient protocol for genomic DNA extraction fromCitrus species. Plant Molecular Biology Reporter, 21(2), 177-178.

Fukao, T., \& Bailey-Serres, J. (2008). 钧 Submergence tolerance conferred by Sub1A is mediated by SLR1 and SLRL1 restriction of gibberellin responses in rice. Proceedings of the National Academy of Sciences, 105(43), 16814-16819.

Galuh Permana, D., Soegianto, A., \& E Kuswanto, D. (2018). Respon Enam Varietas Unggul Tebu Terhadap Genangan The Response Of Six Superior Sugarcane Varieties Again Flood. Jurnal Produksi Tanaman,
6(6), 1195-1203.

Glaz, B., Morris, D. R., \& Daroub, S. H. 的 (2004). Periodic flooding and water table effects on two sugarcane genotypes. Agronomy Journal, 96(3), 832-838.

Gusmiatun, G., Palembang, U. M., 到 Suwignyo, R. A., Sriwijaya, U., Wijaya, A., Sriwijaya, U., \& Hasmeda, M. (2015). Peningkatan Toleransi Rendaman Padi Lokal Rawa Lebak dengan Introgresi Gen Sub1. (May 2017). https://doi.org/10.24831/jai.v43i2.10 409

Hoque, E., \& Ability, C. (2017). Ex Expression of $S U B 1$ gene in relation with different submergence tolerance mechanisms in rice (Oryza sativa $L$ .).

Mackill, D. J., Ismail, A. M., Singh, U. S., 琶 Labios, R. V, \& Paris, T. R. (2012). Development and rapid adoption of submergence-tolerant (Sub1) rice varieties. In Advances in agronomy (Vol. 115, pp. 299-352). Elsevier.

Murtiyaningsih, H., Pertanian, F., \& 理 Jember, U. M. (n.d.). Isolasi DNA Genom dan Identifikasi Kekerabatan Genetik Nanas Menggunakan RAPD (Random Amplified Polimorfic DNA) [DNA Genom Isolation And Identification Of Genetic Relationship Pineapple Usingrapd (Random Amplified Polimorfic DNA)]. In jurnal.unmuhjember.ac.id.

Perata, P., \& Voesenek, L. A. C. J. (2007). 㰯 Submergence tolerance in rice requires Sub1A, an ethyleneresponse-factor-like gene. Trends in Plant Science, 12(2), 43-46. 
Permana, D. G., Winarsih, S., Soegianto, 钢 A., \& Kuswanto, K. (2018). Respon Enam Varietas Unggul Tebu Terhadap Genangan. Jurnal Produksi Tanaman, 6(6).

Ramadhan, R. (n.d.). Studi Pertumbuhan EQ Tanaman Tebu Toleran Cekaman Air Berdasarkan Karakter Fisiologisnya. In repository.unej.ac.id.

Santos, R. S., Krüger, M. M., Pegoraro, C., EQ Madabula, F. P., Maia, L. C., Rombaldi, C. V., \& de Oliveira, A. C. (2013). Transcriptional regulation of seven ERFs in rice under oxygen depletion and iron overload stress. Tropical Plant Biology, 1(6), 16-25.

Schreinert, R., Farias, R., Pegoraro, C., EQ Rombaldi, C. V., Fukao, T., Wing, R. A., \& Oliveira, A. C. De. (2017). Evolutionary analysis of the SUB1 locus across the Oryza genomes. 3-7.

Septiningsih, E. M., Pamplona, A. M., EQ Sanchez, D. L., Neeraja, C. N., Vergara, G. V., Heuer, S., ... Mackill, D. J. (2009). Development of submergence-tolerant rice cultivars: the Sub1 locus and beyond. Annals of Botany, 103(2), 151-160.

Statistik, B. S.-J. (ID): B. P., \& 2015, 钢 undefined. (n.d.). Statistik Tebu Indonesia.

Syahfitri, A., Staf, H., Program, P., \& 到 Agroekoteknologi, S. (2017). Uji Kualitas Dan Kuantitas Dna Beberapa Populasi Pohon Kapur Sumatera. In jurnal.pancabudi.ac.id.

Tetsushi, H., Studies, M. K.-S. P., \& 2007, 尌 undefined. (n.d.). Flooding tolerance of sugarcane in relation to growth, physiology and root structure. In ir.kagoshima-u.ac.jp.
Tiwari, D. N. (2018). A Critical Review of 淂 Submergence Tolerance Breeding beyond Sub 1 Gene to Mega Varieties in the Context of Climate Change. (March).

$\mathrm{Xu}, \mathrm{K}$, \& Mackill, D. J. (n.d.). A Microsatellite Marker and A Codominant PCR-Based Marker For Marker-Assisted Selection of Submergence Tolerance in Rice Implementation Plans to Disseminate Submergence Tolearnt Rice Varieties And Associated Production Practices To Souteastasia View Project. Wiley Online Library. 